Jakub Kostecki*, Andrzej Greinert*, Róża Wasylewicz*, Roksana Adam**, Bartłomiej Garbera**, Przemysław Knap**, Maciej Ostapkowicz ${ }^{* *}$, Bartosz Stanisławiak ${ }^{* *}$

\title{
Spatial distribution of heavy metals in the topsoil on roundabouts in Zielona Góra, Poland
}

\section{Zanieczyszczenie metalami ciężkimi obszaru rond w Zielonej Górze}

*Drinż. Jakub Kostecki, drhab. inż. Andrzej Greinert, drinż. Róża Wasylewicz, Faculty of Civil and Environmental Engineering, Institute of Environmental Engineering, University of Zielona Góra, Prof. Z. Szafrana 15 St., 65-516 Zielona Góra, Poland; phone: +48 68 3282407; e-mail: J.Kostecki@iis.uz.zgora.pi

Keywords: roadside, roundabout, heavy metal, traffic pollution, geo-accumulation index

Słowa kluczowe: tereny przydrożne, ronda, metale ciężkie, zanieczyszczenia komunikacyjne, indeks geo-akumulacji

\begin{abstract}
In most cases, traffic pollution deposition is linear with regularities in its distribution in transect routes (canyon-type effect). The aim of this study is to identify different characteristics of heavy metal deposition on large roundabouts, which are open spaces atypical in terms of the characteristics of the air mass flow along road lanes. The study was conducted on four large roundabouts in Zielona Góra. The content of the selected elements in the tested soils was: Cd 0.54-1.22 mg $\mathrm{kg}^{-1}$ d.m., $\mathrm{Cu} 3.60-29.3 \mathrm{mg} \cdot \mathrm{kg}^{-1}$ d.m., Cr 2.17-4.63 mg.kg-1 d.m., Zn 26.6-89.9 mg $\mathrm{kg}^{-1}$ d.m., Pb $10.9-75.4 \mathrm{mg} \cdot \mathrm{kg}^{-1} \mathrm{~d} . \mathrm{m}$. The geo-accumulation index was also calculated. The threshold values for communication areas were not exceeded, and the content of the elements was generally comparable between the roundabouts. However, we found some differences within particular roundabouts.
\end{abstract}

(C) IOŚ-PIB

\section{INTRODUCTION}

Traffic is becoming more and more serious as an environmental problem despite the solutions that have been introduced, such as the already widespread use of unleaded petrol. The increasing number of vehicles makes it necessary to regard this issue as very serious. In 2012 in Poland, 22,872,000 vehicles (cars, trucks, buses and motorcycles) were registered, of which in the Lubuskie Voivodship nearly 670,000, in Zielona Góra 68,100 [GUS 2013]. This means an increase in the number of vehicles compared to 2005 by $136 \%$ on country level, nearly $146 \%$ on regional level and $134 \%$ in the town of Zielona Góra [GUS 2013]. On Polish roads among vehicles that are up to 5 years old, there are only $10.2 \%$ passenger cars, $9.3 \%$ buses, $16.1 \%$ trucks and $28.3 \%$ tractors. This poses a real threat in terms of traffic emissions (which are higher than acceptable values), which in Poland are on an average level of at 83.9 thous. $\mathrm{Mg}$ of dust and 0.016 thous. $\mathrm{Mg}$ of $\mathrm{Pb}$ (in this number 6.9 thous. Mg of dust and 0.014 thous. $\mathrm{Mg}$ of $\mathrm{Pb}$ from passenger cars) [GUS 2013].
** Roksana Adam, Bartomiej Garbera, Przemysław Knap, Maciej Ostapkowicz, Bartosz Stanisławiak, students, Institute of Environmental Engineering, University of Zielona Góra, Prof. Z. Szafrana 15 St., 65-516 Zielona Góra, Poland

\section{Streszczenie}

W większości przypadków depozycja zanieczyszczeń komunikacyjnych ma charakter liniowy wykazując prawidłowości w rozlokowaniu w transekcie drogi (canyon-type effect). Celem pracy było wskazanie odmiennej charakterystyki depozycji metali ciężkich na dużych rondach będących przestrzeniami otwartymi o nietypowej dla pasa drogowego charakterystyce przepływu mas powietrza. Badania przeprowadzono na czterech dużych obiektach w Zielonej Górze. Wykazano zawartość poszczególnych pierwiastków na poziomie odpowiednio: Cd 0.54-1.22 mg.kg-1 s.m., Cu 3.60-29.3 mg. $\mathrm{kg}^{-1}$ s.m., Cr 2.17-4.63 mg $\mathrm{kg}^{-1}$ s.m., Zn 26.6-89.9 mg $\mathrm{kg}^{-1}$ s.m., Pb 10.9$75.4 \mathrm{mg} \cdot \mathrm{kg}^{-1}$ s.m. Analizowano również indeks geoakumulacji. Nie stwierdzono przekroczenia limitów przewidzianych dla terenów komunikacyjnych, a zawartość pierwiastków pomiędzy rondami była na ogół porównywalna, jednakże stwierdzono pewne różnice w obrębie poszczególnych rond.
The source of heavy metals in roadside soils is mainly dust from car fumes and the road surface (including paints used for painting lanes) [Walczak et al. 2011]. The deposition of heavy metals in roadside areas is described as decreasing as the distance from the edge of the road increases, but in a differentiated manner depending on the form of use of roadside land [Shaohua Wu et al., 2011, Bakirdere and Yaman 2008, Viard et al., 2004, Właśniewski 2007, Kubus et al. 2013, Kwasowski 2013, RojRojewski and Klimaszewska 2014].

For many years, solutions have been sought to improve road communications, especially in urban areas. This may not only bring an economic effect, but also an environmental one: a reduction in high emissions associated with the instantaneous acceleration and deceleration of vehicles. One of the most frequently used solutions is to design intersections as roundabouts. The total number of roundabouts in Zielona Góra is 28 , which in a mediumsized town has a significant impact on communication. Five of 
them are classified as large roundabout - with a diameter of more than $50 \mathrm{~m}$ [Sawyer et al. 2001]. In contrast to linear deposition along the roads, roundabout areas are affected by more complex fluctuations of air masses, which is connected with thermal conditions [Greinert 2011, Suresh Pandian et al. 2011].

\section{MATERIAL AND METHODS}

Four roundabouts located at the northern bypass road of the town were chosen for these studies: The location of the roundabouts in the city is shown in Fig. 1. The main spatial characteristics of the described roundabouts are summarised in Table 2.

The roundabouts were constructed at the turn of the $20^{\text {th }}$ and $21^{\text {st }}$ centuries and until now have been reconstructed several times, R1, R2 and R3 for the last time in 2013-2014. The described roundabouts are non-signalised. The described roundabouts are relative big - with the total area $12,300-17,700 \mathrm{~m}^{2}$, area of the central island $4900-7700 \mathrm{~m}^{2}$ and diameter of the central island 79-99 m. They are covered with the lawn. Traffic on the roundabouts could be described as relatively large - in the year 2014 on the Trasa Północna nearly 16,500 vehicles per hour were noted. The adjacent area is developed mainly as forest ( $R 1$, R3, R4) and services (R1, R2).

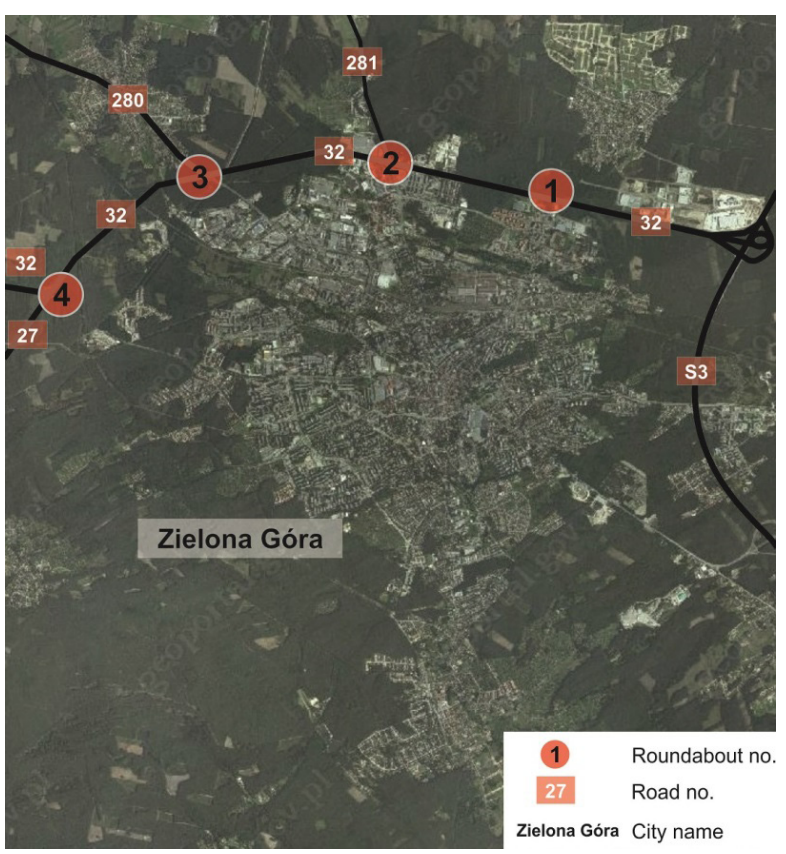

Fig. 1. Site location (on the base of Geoportal 2015)

Primarily, the described area was covered with Haplic Podzols (Arenic), according to IUSS Working Group WRB (2014). Until now, these soils have been typical of areas under forest development. The traffic area, including roundabouts, was transformed mechanically, which resulted in formation of Technosols: Ekranic Technosols (Arenic, Relocatic), Urbic Technosols (Arenic, Relocatic), according to IUSS Working Group WRB (2014) and Charzyński (2006) elaboration.

Due to the specific shape of the selected areas, the roundabouts in Zielona Góra should be treated as a kind of dry logs of forest ecosystems - with higher temperatures and lower humidity
[Findell and Knutson, 2006]. Each of the roundabouts (depending on their size) was divided into 4 zones: the central part - $C$ (the diameters of the central part were respectively 15,17 and $19 \mathrm{~m}$ ), the middle ring - $\mathrm{M}(16 / 18 / 20 \mathrm{~m})$, the outer ring - O (20/20/19 m) and the splitter islands. An example of the division is shown in Fig. 2.

Soil samples were taken in the summer of 2013, from the surface level (up to $20 \mathrm{~cm}$ ). Each sample was collected as a mixed one, representing material from the whole depth of the horizon. The soil material was air-dried and sieved through a sieve with a mesh diameter of $2.0 \mathrm{~mm}$.

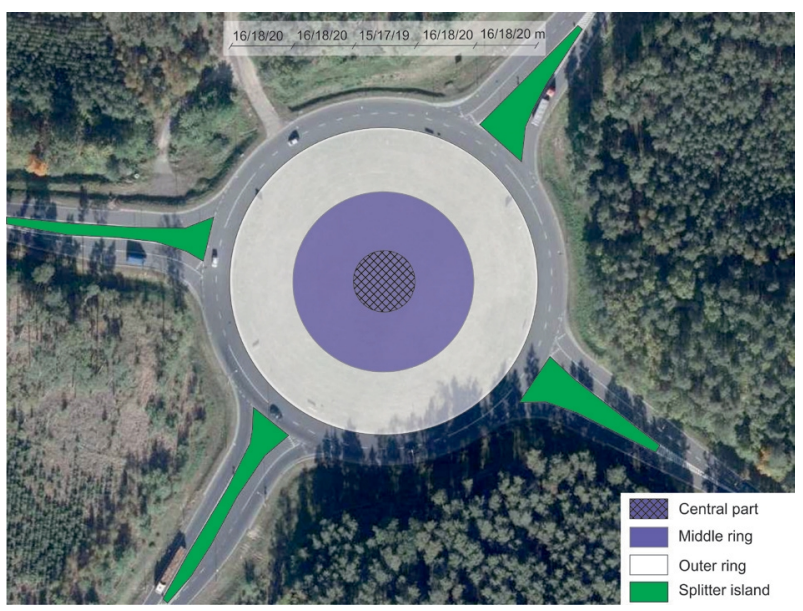

Fig. 2. The scheme of roundabouts divisions (Geoportal 2015)

The particle size distribution was determined by sieving for parts above $2 \mathrm{~mm}$ and using the hydrometer method for sand, silt and clay particles. The $\mathrm{pH}-\mathrm{H}_{2} \mathrm{O}$ and $\mathrm{pH}-1 \mathrm{M} \mathrm{KCl}$ values were measured with a glass electrode WTW SenTix 41 in the 1:2.5 soil: supernatant suspension. The hydrolytic acidity (HA) was determined with the titration method after the addition of sodium acetate to the soil sample and titration with $0.1 \mathrm{M} \mathrm{NaOH}$ to the $\mathrm{pH} 8.25$. The exchangeable bases (EB) were estimated using flame photometry after they had been displaced from the soil sorption complex with $1 \mathrm{M}$ ammonium chloride ( $\mathrm{pH}$ 8.2). The cation exchange capacity (CEC) was calculated as the sum of $\mathrm{HA}$ and $\mathrm{EB}$, and the base saturation (BS) as a share of EB in CEC. The TC content was determined using a NDIR Shimadzu analyzer TOC-VCSN with an SSM 5000A adapter. The electrical conductivity (EC) of the soilwater extract was determined using the conductometric method. In order to determine the content of carbonates in the soil samples, the ISO 10693 method was used, based on the displacement of carbon dioxide by hydrochloric acid addition.

Extracts of the soil samples in aqua regia (the mixture of concentrated acids $\mathrm{HCl}: \mathrm{HNO}_{3}$ in the proportion of $3: 1$ ) were prepared according to PN-ISO 11466:2002. The content of Cd, $\mathrm{Cr}, \mathrm{Cu}, \mathrm{Pb}$ and $\mathrm{Zn}$ in the soil samples was determined by atomic absorption FAAS.

All the soil analyses were performed in triplicate. All statistical analyses were conducted using procedures of StatSoft Statistica 10 for Windows. The basic statistical figures were defined together with correlations between soil condition indices on the levels $\alpha=0.01$ and 0.05 . 
The geo-accumulation index $\left(\mathrm{I}_{\text {geo }}\right)$ was calculated as $I_{\text {geo }}=\log _{2}\left(C_{n} / 1,5 B_{n}\right)$ [Muller 1969] where $C_{n}$ is the concentration of the trace element in the tested sample and $B_{n}$ - the geochemical background value in the soil.

\section{RESULTS AND DISCUSSION}

\subsection{Traffic area transformations}

Soils of the traffic area were transformed as a result of multifactorial impact. The soil profiles were rebuilt during the construction of the roadway. Due to the low thicknesses of topsoil horizons, the human impact during these phases of changes resulted in transformation down to the parent material horizon. The transformations of soil profiles were noted as wider than the road line, which is typical of large-scale construction work. Within the road line, the soils are decapitated, covered with mineral material, compacted and sealed with an impermeable surface. The soils in the area nearby were usually transformed as a consequence of wastes present (mainly rubble, slag and municipal wastes), mixed, compacted and finally covered with organic material - preparation for the roadside green (Fig. 3). The soil profiles have been changed up to $50-100 \mathrm{~cm}$ deep, depending on soil location and human activities during the roundabout construction and land use.

\subsection{Soil properties description}

The particle size distribution of the soils from the tested roundabouts is mostly sand. Only the middle and outer link of roundabout No. 3 was loamy sand. The highest content of soil skeleton was noted in the centre and the island of each roundabout (Table 1).

The reaction of the tested soils is slightly acidic and neutral. The lowest $\mathrm{pH}$ values were found mainly in the centre of the tested roundabouts, the highest $\mathrm{pH}$ was noted on the outer ring (Table 2). The content of organic carbon was low (range from 0.57 to 1.37). Only in the selected soils from roundabouts No. 2 and 3 (respectively from the centre and the island, the island and the middle and the outer ring), the TOC content was higher than $1 \%$. Because of sandy texture and the low TOC content, the CEC reached 2.0-14.4 (av. $5.8 \pm 3.0) \mathrm{cmol} \cdot \mathrm{kg}^{-1}$.

\subsection{Heavy metal content in topsoil}

The soil of the tested roundabouts has a diverse content of heavy metals: Cd 0.54-1.22 $\mathrm{mg} \cdot \mathrm{kg}^{-1} \mathrm{~d} . \mathrm{m}$., Cu $3.60-29.3 \mathrm{mg} \cdot \mathrm{kg}^{-1}$ d.m., Cr 2.17-4.63 mg $\mathrm{kg}^{-1}$ d.m., Zn 26.6-89.9 mg $\mathrm{kg}^{-1}$ d.m., Pb 10.9-75.4 mg $\mathrm{kg}^{-1}$ d.m. (Fig. 3-7). The differences in the content of metals can be observed in different parts of the roundabouts. The highest variability was found in the samples from roundabout No. 2 - especially in the central part (the highest content of $\mathrm{Zn}, \mathrm{Pb}$ and $\mathrm{Cu}$ ). The level of $\mathrm{Cd}$ and $\mathrm{Cr}$ was similar in all other cases. Generally, the lower content of $\mathrm{Cu}, \mathrm{Pb}, \mathrm{Zn}$ - described by many authors as typical for the traffic environmental impact - was determined in central part of the roundabouts. It should be combined with the large size of the roundabout - distance about $40 \mathrm{~m}$ to the edge of the road line. Different observation for $\mathrm{Cd}$ and $\mathrm{Cr}$ were made, showing differentiation in soil material construction, including the waste content. Decrease of the heavy
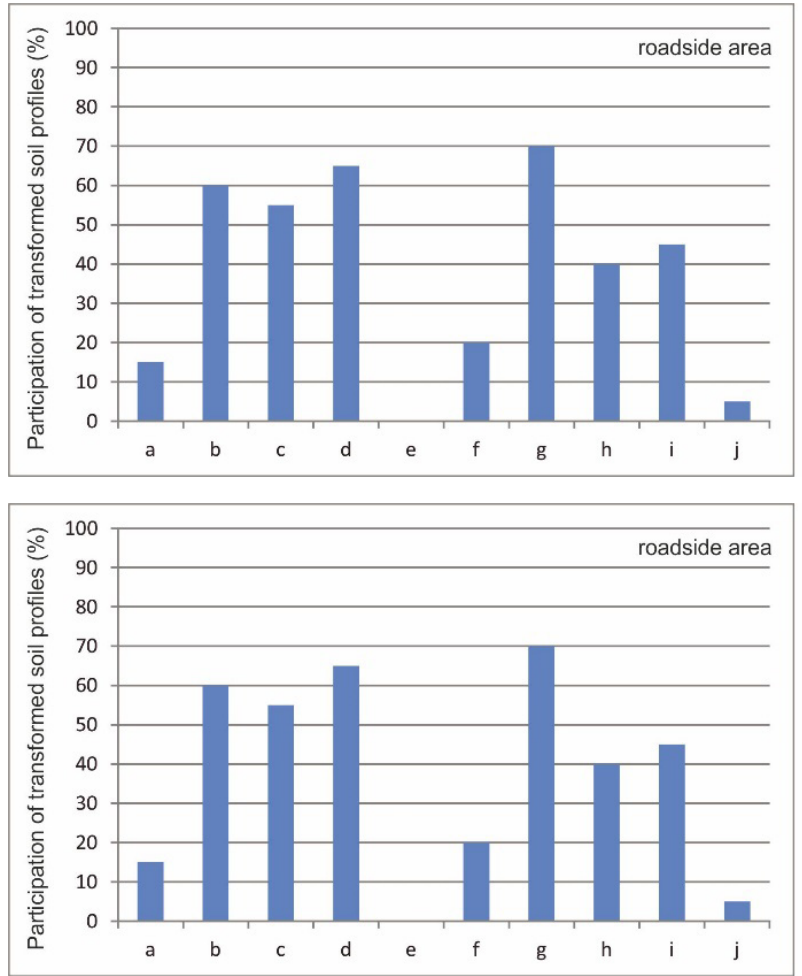

Explanations: $a$ - decapitation of the soil profile, $b$ - presence of municipal wastes, c - superficial deposition of wastes, $d$ presence of building rubble, $e$ - soil sealing, $f$ - covering of the soil with mineral material, $g$ - covering of the soil with organic material, $\mathrm{h}$ - compactness, $\mathrm{i}$ - mixing of the soil horizons, $\mathrm{j}$ - lack of transformations (unchanged soil profile)

Fig. 3. Transformation of the soil profile in the traffic area of the town of Zielona Góra

metals content with the distance from the road is widely presented in literature [Curzydło 1995, Maciejewska and Skłodowski 1995, Właśniewski 2007, Bieniek and Bieniek 2008, Roj-Rojewski and Klimaszewska 2014]. All results are shown in Table 3.

The content of heavy metals in the soil is influenced by a number of factors: the presence of elements in the bedrock (of natural and anthropogenic origin), the presence of admixtures to soil (especially wastes), particle size distribution, organic matter content, land use, plant cover, exposure to air pollution, especially generated by industry and traffic and exposure for direct contamination, that is, as a result of road accidents [KabataPendias and Pendias 2001, Sauve et al. 1998, Greinert 2013, Gustafsson et al. 2011, Fleming et al. 2013, Kwasowski 2013]. A very important factor for lead sorption, besides the organic matter and clay content is soil reaction [Sauve et al. 1998, Właśniewski 2007, Gustafsson et al. 2011, Fleming et al. 2013]. A majority of heavy metals (including $\mathrm{Cd}, \mathrm{Cu}, \mathrm{Cr}, \mathrm{Pb}, \mathrm{Zn}$ ) show better solubility when soil reaction is low [Kabata-Pendias and Pendias 2001, Właśniewski 2007, Roj-Rojewski and Klimaszewska 2014].

The Polish regulation on soil and earth quality standards [OJ 2002 No. 165, item. 1359] specifies high threshold values for areas of communication routes (and industrial ones). In none of the analysed roundabouts were these values exceeded. 
Table 1. Particle size distribution of soils

\begin{tabular}{|c|c|c|c|c|c|}
\hline \multirow[t]{2}{*}{ Roundabout no. } & \multirow[t]{2}{*}{ Site location } & $\begin{array}{c}\text { Sand } \\
(2.0-0.05 \mathrm{~mm})\end{array}$ & $\begin{array}{c}\text { Silt } \\
(0.05-0.002 \mathrm{~mm})\end{array}$ & $\begin{array}{c}\text { Clay } \\
(<0.002 \mathrm{~mm})\end{array}$ & $\begin{array}{l}\text { Soil skeleton } \\
\text { (>2 } \mathrm{mm})\end{array}$ \\
\hline & & \multicolumn{4}{|c|}{$\%$} \\
\hline \multirow{4}{*}{$\mathrm{R} 1$} & Central part & 89 & 10 & 1 & 17.7 \\
\hline & Middle ring & 89 & 8 & 3 & 13.4 \\
\hline & Outer ring & 93 & 6 & 1 & 11.0 \\
\hline & Splitter island & 93 & 7 & 0 & 19.0 \\
\hline \multirow{4}{*}{$\mathrm{R} 2$} & Central part & 89 & 10 & 1 & 16.5 \\
\hline & Middle ring & 93 & 6 & 1 & 12.1 \\
\hline & Outer ring & 91 & 7 & 2 & 15.2 \\
\hline & Splitter island & 92 & 8 & 0 & 13.4 \\
\hline \multirow{4}{*}{ R3 } & Central part & 90 & 10 & 0 & 16.0 \\
\hline & Middle ring & 95 & 4 & 1 & 7.57 \\
\hline & Outer ring & 93 & 7 & 0 & 8.16 \\
\hline & Splitter island & 91 & 9 & 0 & 10.6 \\
\hline \multirow{4}{*}{$\mathrm{R} 4$} & Central part & 85 & 11 & 4 & 26.4 \\
\hline & Middle ring & 84 & 11 & 5 & 20.9 \\
\hline & Outer ring & 88 & 10 & 2 & 22.9 \\
\hline & Splitter island & 91 & 7 & 2 & 23.7 \\
\hline \multicolumn{2}{|c|}{ Mean } & 90.4 & 8.2 & 1.4 & 15.9 \\
\hline \multicolumn{2}{|c|}{ Min. } & 84 & 4 & 0 & 7.57 \\
\hline \multicolumn{2}{|c|}{ Max. } & 95 & 11 & 5 & 26.4 \\
\hline \multicolumn{2}{|c|}{ Standard deviation } & 2.9 & 2.0 & 1.5 & 5.4 \\
\hline
\end{tabular}

Table 2. Selected properties of soils

\begin{tabular}{|c|c|c|c|c|c|c|c|c|c|}
\hline \multirow{2}{*}{ Roundabout no. } & \multirow{2}{*}{ Site location } & HA & TEB & CEC & BS & $\mathrm{CO}_{3}{ }^{2-}$ & TOC & \multicolumn{2}{|c|}{$\mathrm{pH}$} \\
\hline & & \multicolumn{3}{|c|}{$\mathbf{c m o l} \cdot \mathbf{k g}^{-1}$} & \multicolumn{3}{|c|}{$\%$} & $\mathrm{H}_{2} \mathrm{O}$ & $\mathrm{KCl}$ \\
\hline \multirow{4}{*}{ R1 } & Central part & 4.80 & 1.4 & 2.8 & 7.6 & 0 & 0.57 & 6.12 & 4.91 \\
\hline & Middle ring & 3.60 & 2.9 & 5.8 & 9.4 & 0 & 0.75 & 6.98 & 6.84 \\
\hline & Outer ring & 2.40 & 4.2 & 8.4 & 10.8 & 0 & 0.61 & 7.36 & 7.23 \\
\hline & Splitter island & 2.70 & 2.8 & 5.6 & 8.3 & 0 & 0.72 & 7.27 & 6.91 \\
\hline \multirow{4}{*}{$\mathrm{R} 2$} & Central part & 5.10 & 2.3 & 4.5 & 9.6 & 0 & 0.82 & 6.62 & 6.49 \\
\hline & Middle ring & 3.80 & 2.1 & 3.6 & 7.4 & 0 & 0.75 & 6.21 & 6.10 \\
\hline & Outer ring & 3.10 & 1.5 & 2.7 & 5.8 & 0 & 0.71 & 6.25 & 6.05 \\
\hline & Splitter island & 3.20 & 2.2 & 4.1 & 7.3 & 0 & 0.80 & 5.90 & 5.80 \\
\hline \multirow{4}{*}{ R3 } & Central part & 5.70 & 2.1 & 4.2 & 9.9 & 0 & 1.18 & 6.29 & 5.70 \\
\hline & Middle ring & 3.90 & 1.0 & 2.0 & 5.9 & 0 & 0.58 & 6.60 & 5.94 \\
\hline & Outer ring & 3.30 & 2.4 & 4.8 & 8.1 & 0 & 0.73 & 6.97 & 6.72 \\
\hline & Splitter island & 3.60 & 3.5 & 7.0 & 10.6 & 0 & 1.21 & 7.11 & 6.20 \\
\hline \multirow{4}{*}{ R4 } & Central part & 2.10 & 3.7 & 7.4 & 9.5 & $<3$ & 0.69 & 7.02 & 7.05 \\
\hline & Middle ring & 3.60 & 3.7 & 7.4 & 11.0 & 0 & 1.06 & 6.57 & 6.24 \\
\hline & Outer ring & 2.70 & 7.2 & 14.4 & 17.1 & 0 & 1.28 & 7.13 & 7.12 \\
\hline & Splitter island & 6.30 & 4.4 & 8.8 & 15.1 & 0 & 1.37 & 6.26 & 5.45 \\
\hline
\end{tabular}


Table 2. Selected properties of soils

\begin{tabular}{|c|c|c|c|c|c|c|c|c|c|}
\hline \multirow{2}{*}{ Roundabout no. } & \multirow{2}{*}{ Site location } & HA & TEB & CEC & BS & $\mathrm{CO}_{3}^{2-}$ & TOC & & \\
\hline & & \multicolumn{3}{|c|}{$\mathbf{c m o l} \cdot \mathbf{k g}^{-1}$} & \multicolumn{3}{|c|}{$\%$} & $\mathrm{H}_{2} \mathrm{O}$ & $\mathrm{KCl}$ \\
\hline \multicolumn{2}{|c|}{ Mean } & 3.7 & 3.0 & 5.8 & 9.6 & 0.0 & 0.9 & 6.7 & 6.3 \\
\hline \multicolumn{2}{|c|}{ Min. } & 2.1 & 1.0 & 2.0 & 5.8 & 0.0 & 0.57 & 5.9 & 4.91 \\
\hline \multicolumn{2}{|c|}{ Max. } & 6.3 & 7.2 & 14.4 & 17.1 & 0.0 & 1.37 & 7.36 & 7.23 \\
\hline \multicolumn{2}{|c|}{ Standard deviation } & 1.1 & 1.5 & 3.0 & 2.9 & 0.0 & 0.3 & 0.4 & 0.6 \\
\hline
\end{tabular}

Explanations: HA - hydrolytic acidity, TEB - total exchangeable bases, CEC - cation exchange capacity, BS - base saturation, TOC - organic carbon

Table 3. The content of heavy metals in the tested topsoils

\begin{tabular}{|c|c|c|c|c|c|c|}
\hline \multirow{2}{*}{ Roundabout no. } & \multirow{2}{*}{ Site location } & Cd & $\mathrm{Cr}$ & $\mathrm{Cu}$ & $\mathrm{Pb}$ & $\mathrm{Zn}$ \\
\hline & & \multicolumn{5}{|c|}{$\mathrm{mg} \cdot \mathrm{kg}^{-1}$ d.m. } \\
\hline \multirow{4}{*}{$\mathrm{R} 1$} & Central part & 0.98 & 2.17 & 5.99 & 12.2 & 26.6 \\
\hline & Middle ring & 1.07 & 3.46 & 3.98 & 11.9 & 30.3 \\
\hline & Outer ring & 0.64 & 2.61 & 3.78 & 10.9 & 26.8 \\
\hline & Splitter island & 0.54 & 3.51 & 13.8 & 23.6 & 56.5 \\
\hline \multirow{4}{*}{ R2 } & Central part & 1.13 & 3.03 & 4.79 & 16.2 & 34.0 \\
\hline & Middle ring & 0.80 & 3.41 & 29.3 & 75.4 & 89.9 \\
\hline & Outer ring & 0.96 & 2.44 & 7.19 & 21.4 & 47.8 \\
\hline & Splitter island & 0.96 & 3.33 & 11.6 & 18.7 & 52.6 \\
\hline \multirow{4}{*}{ R3 } & Central part & 1.22 & 4.04 & 3.60 & 14.2 & 35.2 \\
\hline & Middle ring & 0.65 & 4.63 & 4.81 & 18.3 & 51.2 \\
\hline & Outer ring & 0.81 & 3.25 & 9.63 & 29.1 & 44.1 \\
\hline & Splitter island & 0.80 & 2.52 & 10.4 & 17.6 & 41.8 \\
\hline \multirow{4}{*}{ R4 } & Central part & 1.10 & 3.10 & 5.10 & 15.1 & 29.7 \\
\hline & Middle ring & 0.86 & 3.50 & 4.50 & 21.2 & 41.5 \\
\hline & Outer ring & 0.78 & 2.70 & 8.60 & 22.4 & 40.4 \\
\hline & Splitter island & 0.80 & 3.20 & 12.2 & 19.7 & 49.6 \\
\hline \multicolumn{2}{|c|}{ Mean } & 0.88 & 3.18 & 8.71 & 21.7 & 43.6 \\
\hline \multicolumn{2}{|c|}{ Min. } & 0.54 & 2.17 & 3.60 & 10.9 & 26.6 \\
\hline \multicolumn{2}{|c|}{ Max. } & 1.22 & 4.63 & 29.3 & 75.4 & 89.9 \\
\hline \multicolumn{2}{|c|}{ Standard deviation } & 0.18 & 0.60 & 6.22 & 14.6 & 15.1 \\
\hline
\end{tabular}

Besides the threshold values, some other techniques of risk assessment can be used, for example, the geo-accumulation index. For each metal, the $\mathrm{I}_{\text {geo }}$ is classified as: uncontaminated $\left(\mathrm{I}_{\text {geo }} \leq 0\right)$, uncontaminated to moderately contaminated $\left(0<\mathrm{I}_{\text {geo }} \leq 1\right)$, moderately contaminated $\left(1<\mathrm{I}_{\text {geo }} \leq 2\right)$, moderately to heavily contaminated $\left(2<\mathrm{I}_{\text {geo }} \leq 3\right)$; heavily contaminated $\left(3<\mathrm{I}_{\text {geo }} \leq 4\right)$, heavily to extremely contaminated $\left(4<\mathrm{I}_{\text {geo }} \leq 5\right)$ and extremely contaminated $\left(I_{\text {geo }} \geq 5\right)$ [Muller 1969].

The data obtained show (Table 4) that the element, which creates the greatest risk is cadmium ( $I_{\text {geo }}>3$, in all locations), the lowest risk to the environment is caused by chromium $\left(I_{\text {geo }}<1\right)$. Due to pollution with more than one element, the highest environmental risk was found in the soil of the middle ring of roundabout No. 2 (for $\mathrm{Zn}, \mathrm{Cu}, \mathrm{Cd}, \mathrm{Pb}$ ). The geo-accumulation index for the other roundabouts was similar.

\subsection{Spatial conditions of heavy metals distribution}

Westerly winds (W, SW, NW) are the most frequent in Zielona Góra (WIOS 2010). Industrial activity is located in the northern part of the town, the tested roundabouts are located at a considerable distance from residential areas. These facts have an impact on the contents of the selected heavy metals in the studied soil. The varied heavy metal content in the traffic areas results not only from climatic conditions, land use and physicochemical properties of soils, but also from traffic intensity, vehicle age and the type of fuel used. Werkenthin et al 2014 show that 
Table 4. Geo-accumulation index

\begin{tabular}{|c|c|c|c|c|c|c|}
\hline Roundabout no. & Site location & $\mathrm{I}_{\text {geo Cd }}$ * & $\mathrm{I}_{\mathrm{geo} \mathrm{Cr}}{ }^{* *}$ & $\mathrm{I}_{\text {geo Cu}}{ }^{*}$ & $\mathrm{I}_{\text {geo Pb }}$ * & $\mathrm{I}_{\text {geo } \mathrm{Zn}}$ * \\
\hline \multirow{4}{*}{$\mathrm{R} 1$} & Central part & 5.0 & 0.0 & 0.8 & 1.3 & 0.8 \\
\hline & Middle ring & 5.5 & 0.1 & 0.5 & 1.3 & 0.9 \\
\hline & Outer ring & 3.3 & 0.1 & 0.5 & 1.2 & 0.8 \\
\hline & Splitter island & 2.8 & 0.1 & 1.7 & 2.5 & 1.7 \\
\hline \multirow{4}{*}{$\mathrm{R} 2$} & Central part & 4.6 & 0.0 & 0.5 & 1.6 & 0.9 \\
\hline & Middle ring & 5.4 & 0.1 & 0.5 & 1.3 & 1.0 \\
\hline & Outer ring & 3.6 & 0.1 & 0.5 & 1.4 & 0.9 \\
\hline & Splitter island & 5.7 & 0.1 & 1.6 & 2.2 & 1.6 \\
\hline \multirow{4}{*}{ R3 } & Central part & 5.8 & 0.1 & 0.6 & 1.7 & 1.0 \\
\hline & Middle ring & 4.1 & 0.1 & 3.7 & 8.0 & 2.8 \\
\hline & Outer ring & 4.9 & 0.0 & 0.9 & 2.3 & 1.5 \\
\hline & Splitter island & 5.0 & 0.1 & 1.5 & 2.0 & 1.6 \\
\hline \multirow{4}{*}{$\mathrm{R} 4$} & Central part & 6.3 & 0.1 & 0.5 & 1.5 & 1.1 \\
\hline & Middle ring & 3.4 & 0.1 & 0.6 & 1.9 & 1.6 \\
\hline & Outer ring & 4.2 & 0.1 & 1.2 & 3.1 & 1.3 \\
\hline & Splitter island & 4.1 & 0.0 & 1.3 & 1.9 & 1.3 \\
\hline
\end{tabular}

Sources: ${ }^{*} B_{n}$ based on Greinert (2003), ${ }^{*} B_{n}$ based on Kabata-Pendias and Pendias (2001)

for the spread of contamination from the boundary of different processes (at a distance up to $10 \mathrm{~m}$ : splashing water and airborne transport of road and traffic-related particles, at further distances mainly airflow). Depending on the analysed elements, the values obtained for Zielona Góra were in some cases similar $(\mathrm{Cd}, \mathrm{Cr}$, $\mathrm{Pb}, \mathrm{Zn})$, lower $(\mathrm{Cd}, \mathrm{Cr})$ and higher $(\mathrm{Cu}, \mathrm{Pb})$ in comparison to roadside areas in other cities, for example, Białystok, Gliwice, Kośmidry, Opole, Szczecin, Zabrze [Czubaszek and Bartoszuk 2011, Sławiński et al. 2014, Kubus et al. 2013, Wawer et al. 2013].

\section{CONCLUSION}

Despite the significant traffic volume, the limits of the standardised content of metals in the soil of the studied areas were not exceeded.

\section{REFERENCES AND LEGAL ACTS}

BAKIRDERE S., YAMAN M. 2008. Determination of lead, cadmium and cooper in roadside soil and plants in Elazig, Turkey. Environ Monit Assess 136, 1-3: 401-410.

BIENIEK A., BIENIEK B. 2008. Heavy metals in soils along traffic arteries of Olsztyn. Roczniki Gleboznawcze, T. 59, No. 3/4: 23-30 (in Polish).

CHARLESWORTH S., EVERETT M., MCCARTHY R., ORDÓÑEZ A., DE MIGUEL, E. 2003. A comparative study of heavy metal concentration and distribution in deposited street dusts in a large and a small urban area: Birmingham and Coventry, West Midlands, UK. Environ. Int., 29: 563573.
The level of contamination within and across the roundabouts in the case of $\mathrm{Cd}$ and $\mathrm{Cr}$ was comparable. The content of $\mathrm{Zn}$, $\mathrm{Pb}$ and $\mathrm{Cu}$ - especially in the central ring of the central part was highest and could cause the highest environmental risk in the future.

The highest metal content occurred in the central part and middle ring of the central islands. A lower content was found at the outer edge of the central part and at the splitter islands.

The geo-accumulation index for $\mathrm{Pb}, \mathrm{Cd}, \mathrm{Cu}, \mathrm{Zn}$ was the highest in the middle ring of roundabout. Only the $\mathrm{Cr}$ content was on 'natural' level. In general, the highest geo-accumulation index was found for cadmium.

CHARZYŃSKI P. 2006. Testing WRB on Polish soils. Association of Polish Adult Educators, Torun Branch.

CHRISTOFODIS A., STAMATIS N. 2009. Heavy metal contamination in street dust and roadside soil along the major national road in Kavala's region, Greece. Geoderma 151 (3-4): 257-263.

CHRISTOFORIDIS A., STAMATIS N. 2009. Heavy metal contamination in street dust and roadside soil along the major national road in Kavala's region, Greece, Geoderma, 151: 257-263.

CURZYDŁO J. 1995. Automotive contamination along roads and highways and the traffic negative effects in the environment 
counteract methods. Zesz. Probl. Post. Nauk Rol. 418: 265-270 (in Polish).

CZUBASZEK R., BARTOSZUK K. 2011. Content of selected heavy metals in soils in accordance with its distance from the street and land use, Civil and Environmental Engineering, 2: 27-34 (in Polish).

DE MIGUEL, E., LLAMAS, J.F., CHACON, E., BERG, T., LARSSEN, S., ROYSET, O., VADSET, M. 1997. Origin and patterns of distribution of trace elements in street dust: unleaded petrol and urban lead. Atmos. Environ., 31: 2733 2740.

DIERKES C., GEIGER, W.F. 1999. Pollution Retention Capabilities of Roadside Soils. Wat. Sci. Tech. 39, 2: 201208.

FINDELL K.L., KNUTSON T.R. 2006. Weak Simulated Extratropical Responses to Complete Tropical Deforestation, J Climate, 19 (12): 2835-2850.

FLEMING M., TAI Y., ZHUANG P., MC BRIDE M.B. 2013. Extractability and bioavailability of $\mathrm{Pb}$ and $\mathrm{As}$ in historically contaminated orchard soil: Effects of compost amendments. Environmental Pollution, 177: 90-97.

GREINERT A. 2003. Studies on soil of urbanized area of Zielona Góra (Studia nad glebami obszaru zurbanizowanego Zielonej Góry, in Polish), Oficyna Wydaw. Uniwersytetu Zielonogórskiego, Zielona Góra.

GREINERT A. 2011. Ecosystems of the urban areas (In:) Plants for special tasks. Ed. by E. Drozdek. Wydaw. Państwowej Wyższej Szkoły Zawodowej, Sulechów (Zieleń Miast i Wsi. Współczesna i Zabytkowa, ISBN: 978-83-60792-17-9): 283-302.

GREINERT A., FRUZIŃSKA R., KOSTECKI J. 2013. Urban soils in Zielona Góra (In:) Technogenic soils of Poland / ed. by P. Charzyński, P. Hulisz, R. Bednarek. Toruń : Polish Society of Soil Science, 31-54.

GUSTAFSSON J.P., TIBERG C., EDKYMISH A., BERGGREN KLEJA D. 2011. Modelling lead (II) sorption to ferrihydrite and soil organic matter. Environmental Chemistry, 8: 485-492.

IUSS Working Group WRB. 2014. World Reference Base for Soil Resources 2014. International soil classification system for naming soils and creating legends for soil maps. World Soil Resources Reports No. 106. FAO, Rome.

KABATA-PENDIAS A., PENDIAS H. 2001. Trace elements in soils and plants. Third Edition. CRC Press LLC, Boca Raton, London, New York, Washington D.C.

KOCHER, B., WESSOLEK, G. and STOFFREGEN, H. 2005. Water and heavy metal transport in roadside soils. Pedosphere, 15, 6: 746-753.

KUBUS M., MALINOWSKI R., MELLER E., MALINOWSKA K., RACEK M. 2013. Soils of traffic areas in Szczecin (In:) Technogenic soils of Poland / ed. by P. Charzyński, P. Hulisz, R. Bednarek. Toruń : Polish Society of Soil Science, 191-205.

KWASOWSKI W. 2013. Soils of traffic areas in Warsaw (In:) Technogenic soils of Poland / ed. by P. Charzyński, P. Hulisz, R. Bednarek. Toruń : Polish Society of Soil Science, 207-229.

LEE, P.K., YU, Y.H., YUN, S.T., MAYER, B. 2005. Metal contamination and solid phase partitioning of metals in urban roadside sediments. Chemosphere, 60: 672-689.

LEWICKI Z., DAMCZYK K. (ed.) 2010. Stan środowiska w Zielonej Górze w latach 2005-2010. Biblioteka Monitoringu Środowiska, Zielona Góra (in Polish).
MACIEJEWSKA A., SKŁODOWSKI P. 1995. The impact of vehicle emissions on soil contamination with lead, zinc and cadmium along the route Warsaw-Katowice. Zesz. Probl. Post. Nauk Rol. 418: 271-280 (in Polish).

MULLER G. 1969. Index of geo-accumulation in sediments of the Rhine River, Geojournal 2: 108-118.

ONIANWA P.C., 2001. Roadside topsoil concentrations of lead and other heavy metals in Ibadan, Nigeria. Soil and Sediment Contamination, 10, 6: 577-591.

PAGOTTO, C., N. REMY, LEGRET, M. \& P. Le Cloirec. 2001. Heavy metal pollution of road dust and roadside soil near a major rural highway. Environmental Technology 22: 307319.

PN-ISO 11466:2002. Jakość gleby -- Ekstrakcja pierwiastków śladowych rozpuszczalnych w wodzie królewskiej. PKN. 2002. Warszawa.

Rocznik Statystyczny Województwa Lubuskiego 2013. GUS, Warszawa.

ROJ-ROJEWSKI S., KLIMASZEWSKA M. 2014. Heavy metals contamination in soils of a small town with intensive road traffic. Pol. J. Environ. Stud. 23, 5: 1711-1717.

Rozporządzenie Ministra Środowiska z dnia 9 września 2002 r. w sprawie standardów jakości gleby oraz standardów jakości ziemi (Dz. U. 2002, nr 165, poz. 1359).

SAUVE S., MCBRIDE M., HENDERSHOT W. 1998. Soil solution speciation of lead: effects of organic matter and $\mathrm{pH}$. Soil Science Society of America Journal 62: 618-621.

SEZGIN N., OZCAN H.K., DEMIR G., NEMLIOGLU S., BAYAT C. 2003. Determination of heavy metal concentrations in street dusts in Istanbul E-5 highway, Environment International 29: 979-985.

SHAOHUA Wu, SHENGLU Zhou, XINGONG Li, TRISH Jackson, QING Zhu. 2011. An approach to partition the anthropogenic and natural components of heavy metal accumulations in roadside agricultural soil. Environ Monit Assess, 173: 871881.

SŁAWIŃSKI J., GOŁĄBEK E., SENDERAK G. 2014. Wpływ zanieczyszczeń komunikacyjnych na glebę i uprawną roślinność przydrożną, Inżynieria Ekologiczna, 40: 137-144 (in Polish).

PANDIAN S., GOKHALE S., GHOSHAL A.K. 2011. An openterrain line source model coupled with street-canyon effects to forecast carbon monoxide at traffic roundabout. Science of the Total Environment 409: 1145-1153.

TANG R., MA K., ZHANG Y., MAO Q. 2013. The spatial characteristics and pollution levels of metals in urban street dust of Beijing, China, Applied Geochemistry 35: 88-98.

VIARD B., PIHAN F., PROMEYRAT S., PIHAN J.C. 2004. Integrated assessment of heavy metal $(\mathrm{Pb}, \mathrm{Zn}, \mathrm{Cd})$ highway pollution: bioaccumulation in soil, Graminaceae and land snails.

WALCZAK B., GREINERT A., GOSK Ł., GÓRKA K. 2011. influence of soil geomechanical transformations in urban communication areas on their physico-chemical properties. Soil Science Annual 62, 2: 421-419.

WAWER M., SZUSZKIEWICZ M., MAGIERA T. 2013. Characteristics of current roadside pollution of soils in upper Silesia (In:) Interdyscyplinarne zagadnienia w inżynierii i ochronie środowiska. Tom 3 /ed. T.M. Traczewska, Oficyna Wydawnicza Politechniki Wrocławskiej, 637-643. 
WERKENTHIN M., KLUGE B., WESSOLEK G. 2014. Metals in European roadside soils and soil solution - A review, Env Pollution 189: 98-110.

WŁAŚNIEWSKI S. 2007. Effect of automotive traffic emissions on the content of heavy metals in soils located close to the national road Rzeszów-Łańcut. Advances of Agricultural Science Problem Issues, 520: 189-200. 